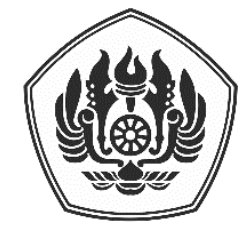

Padjadjaran Journal of International Law

ISSN: 2549-2152, EISSN: 2549-1296

Volume 3, Number 1, January 2019

\title{
Unilateral Claim over Chagos Archipelago as British Indian Ocean Territory (BIOT) by United Kingdom Based on International Law
}

\author{
Jerina Novita Elpasari*
}

\begin{abstract}
In 1965, United Kingdom (UK) made a unilateral claim over the Chagos Archipelago as British Indian Ocean Territory (BIOT) based on the BIOT Order of 1965 and Statutory Instrument of 1965 No. 1020. Due to this unilateral act, the Chagos Archipelago no longer parts of Mauritius. Problem arising from Britain's unilateral claim to the territory was further aggravated by the United Kingdom's act in enforcing population transfer towards all Chagos islanders (Chagossians) out of the territory without adequate compensations and resettlement. This research aims to analyze the legality of unilateral claims over the Chagos archipelago as a BIOT and the enforced transfer of Chagossians from their original residential place by the United Kingdom. It argues that under international law, Chagos Archipelago is recognized as an area that should remain integrated within the territory of Mauritius. It further argues that the UK has violated international law by committing enforced population transfer.
\end{abstract}

Keywords: BIOT, Enforced Population Transfer, Territory, The Chagos Archipelago, Unilateral Act.

\section{Klaim Sepihak Inggris terhadap Kepulauan Chagos sebagai British Indian Ocean Territory (BIOT) Berdasarkan Hukum Internasional}

\begin{abstract}
Abstrak
Pada tahun 1965, Inggris melakukan klaim sepihak atas wilayah Kepulauan Chagos sebagai British Indian Ocean Territory (BIOT) berdasarkan British Indian Ocean Territory Order of 1965 dan Statutory Instrument of 1965 No. 1020. Kepulauan Chagos merupakan bagian dari Mauritius pada saat Mauritius berada dibawah penjajahan Inggris. Tindakan yang dilakukan oleh Inggris terhadap wilayah tersebut berdampak pada terpisahnya kepulauan Chagos dari Mauritius. Permasalahan yang timbul dari Klaim sepihak Inggris atas wilayah tersebut kemudian turut diperparah dengan tindakan Inggris yang melakukan pemindahan paksa seluruh penduduk kepulauan Chagos (Chagossians) dari wilayah tersebut tanpa kompensasi dan tempat tinggal pengganti yang layak serta memadai. Penelitian ini bertujuan untuk menganalisis legalitas klaim sepihak terhadap kepulauan Chagos sebagai BIOT dan pemindahan Chagossians dari tempat tinggal asalnya secara paksa yang dilakukan oleh Inggris sebagai enforced population transfer. Penelitian ini menunjukkan bahwa wilayah kepulauan Chagos diakui sebagai wilayah yang seharusnya tetap terintegrasi dalam wilayah
\end{abstract}

PADJADJARAN JOURNAL OF INTERNATIONAL LAW Volume 3 Number 1 Year 2019 [ISSN 2549-2152] [e-ISSN 2549-1296]

Support Team Department of International Federation of Red Cross and Red Crescent Society - Country Cluster Support Team (IFRCCCST) of Indonesia and Timor Leste, Jl. Wijaya I No. 63 Keb. Baru Jakarta Selatan, jerinanovita01@gmail.com, 
Jerina Novita Elpasari

Unilateral Claim over Chagos Archipelago as British Indian Ocean Territory (BIOT) by

United Kingdom Based on International Law

Mauritius dan penetapan wilayah tersebut sebagai BIOT telah bertentangan dengan prinsip dan ketentuan hukum internasional.

Kata Kunci: BIOT, Enforced Population Transfer, Kepulauan Chagos, Tindakan Sepihak, Wilayah

\section{A. INTRODUCTION}

The Chagos Archipelago consists of approximately 60 tropical islands in the Indian Ocean. It is located about 500 kilometers $(310 \mathrm{mi})$ south of the Maldives archipelago and approximately $800 \mathrm{mi}$ from Mauritius. ${ }^{1}$ The main islands in the Chagos archipelago include Diego Garcia, Peros Banhos, Salomon, and Egmont. ${ }^{2}$ Diego Garcia is the largest island in the Chagos archipelago. $^{3}$ The land area of the Chagos Archipelago is approximately $56.13 \mathrm{~km} 2$ and with a total area (including water areas) of more than $550,000 \mathrm{~km} 2{ }^{4}$

Historically, the Chagos Archipelago is an uninhabited area that was first discovered in 1721 by the French who at that time were exploring around the Mauritius region, an area that France had previously discovered and occupied in the early 18 th century. ${ }^{5}$ Since then, the Chagos Archipelago has been part of occupied Mauritius and under the administration of the French Government. ${ }^{6}$ Government control in the Chagos Archipelago is fully exercised and centered on
Mauritius. ${ }^{7}$ The Chagos Archipelago region which is controlled by France has a very conducive climate and soil conditions to be used as copra plantations. ${ }^{8}$ Under these conditions, France then brought slaves obtained from the Caribbean to the Chagos Archipelago to manage copra plantations there. ${ }^{9}$ The slaves brought by France and their descendants later became the natives who settled on the Chagos Islands. ${ }^{10}$

The large yield and potential of copra plantations in the Chagos Archipelago which are owned by the French government attracted British interest. So that in 17941810 , Britain made active efforts to occupy and seize the Chagos Archipelago from France. ${ }^{11}$ In the end, France's efforts to defend its territory from Britain failed and ended with the Treaty of Paris 1814 which contained provisions for the official transfer of territories controlled by France in the Indian Ocean to Britain. Under the agreement, Mauritius and its part, the Chagos Islands, were officially transferred and ruled under the administration of the British

$1 \quad$ World Wildlife Fund, "Maldives-Lakshadweep-Chagos Archipelago Tropical Moist Forests", Wild World Ecoregion Profile, National Geographic Society, 2001 and Geoffrey Robertson QC, "Who Owns Diego Garcia? Decolonization and Indigenous Rights in the Indian Ocean", University of Western Australia Law Review, Vol. 36, No.1, 2012-2013, p. 3

2 R. Dussercle, The Mission Reports: Archipel de Chagos, Port Louis: General Printing, 1934.

3 Bhatt, the Strategic Role of the Indian Ocean in World Politics: The Case of Diego Garcia, New Delhi: Ajanta, 1992, p. 7

4 Sheppard CRC (et.al.), "Reef and Islands of the Chagos Archipelago, Indian Ocean: Why it is the World's Largest No-Take Marine Protected Area", Aquatic Conservation: Marine and Freshwater Ecosystems Journal, Vol. 22, No. 2, 2012, p. 6.

5 Sandra JTM Evers, and Marry Kooy (eds.), African History: Eviction from the Chagos Archipelago Displacement and Struggle for Identity Against Two World Powers, Leiden: BRILL, 1992, p. ix.

Ibid.

Ibid.

8 Bernardo Gomes de Brito, Tragic Maritime History, Cambridge: Hakluyt Society at the University Press, 1735; Richard Gifford, "The Chagos Island Islands: The Land Where Human Rights Hardly Ever Happened", Law Social Justice \& Global Development Journal, Vol. 1, No.1, 2004; Sydney Selvon, "A New Comprehensive History of Mauritius: From the Beginning to This Day", From British Mauritius to the 21st Century, Vol.2, 2012

$9 \quad$ Ibid.

10 David Vine, "From the Birth of Illinois to the 'Footprint of Freedom': A History of Chagos and Chagossians", in Sandra JTM Evers, and Marry Kooy (ed.), Op.Cit., p. 17

$11 \quad$ Ibid. p. $\mathrm{x}$ 
government. ${ }^{12}$

In 1960, the General Assembly of the United Nations (UN) passed Resolution No. $1514 / 1960$ which instructed the abolition of all forms of colonialism and stated that every individual has equal rights and positions and the right to determine his destiny, including for Mauritius. ${ }^{13}$ This resolution was also strengthened by the issuance of another UN General Assembly Resolution which explicitly instructed the granting of independence to Mauritius. ${ }^{14}$ Based on the provisions of these resolutions, in 1965, negotiations for the independence of Mauritius began. ${ }^{15}$ During the negotiations, Britain proposed the takeover of the Chagos Archipelago from Mauritius in exchange for support for independence preparations and compensations. ${ }^{16}$ However, the negotiations

$12 \quad$ Ibid, p. x-xi

13 "Immediate steps shall be taken, in Trust and Non-SelfGoverning Territories or all other territories which have not yet attained independence, to transfer all powers to the peoples of those territories, without any conditions or reservations, following their freely expressed will and desire, without any distinction as to race, creed or color, to enable them to enjoy complete independence and freedom ". UNGA Resolution No. 1514 (XV) of 14 December 1960: Declaration on the Granting of Independence to Colonial Countries and People.

14 "Call upon States concerned to take actions without further delay with a view to the faithful application and implementation of Declaration (UNGA Resolution No. 1514 (XV) of 14 December 1960)" in UNGA Resolution No. 1654 (XVI) of 27 November 1961: The Situation with Regard to the Implementation of Declaration on the Granting of Independence to Colonial Countries and People; and "Reaffirms the inalienable rights of the people of the territory of Mauritius to freedom and independence in accordance with General Assembly Resolution No.1514 (XV)", "Invites the government of the United Kingdom of Great Britain and Northern Ireland to take effective measures with a view to the immediate and full implementation of General Assembly Resolution No. 1514 (XV) ", in UNGA Resolution No. 2066 (XX) of 16 December 1965:

15 Ministry of Art and Culture of Mauritius, National Day Celebration: Enn Pei, Enn Nation, Enn Destin, Government of Republic Mauritius, 2013, p. 3

16 Sandra JTM Evers, and Marry Kooy (eds.), Op.Cit., p. x-xi.

17 Hansard House of Lords Debates, Mauritius Republic Bill: Baroness Chalker of Wallasey, 19 May 1992, Vol. 537, Par. 584-585. did not come to the agreement of the parties involved. ${ }^{17}$ The failed negotiations regarding the takeover of the Chagos Archipelago by the British then led to the British action which made a unilateral claim over Chagos Archipelago territory as the British Indian Ocean Territory (BIOT) from Mauritius which was carried out by establishing it in the British national law document on 8 November $1965,{ }^{18}$ even before Mauritius was declared independent from Britain in 1968. ${ }^{1920}$ The British action on the Chagos Archipelago region as BIOT can be identified as Unilateral Acts in the form of a unilateral claim on an area carried out by the State. ${ }^{21}$

The British unilateral action that has designated the Chagos Archipelago as BIOT has implications for the emergence of several other legal events which not only affected

18 British Indian Ocean Territory Order (1965); Statutory Instrument of 1965 No. 1920 which later amended by Statutory Instrument of 1968 No. 111; also refer to United States Dept. of State Office of the Geographer, Commonwealth of Nations, US Government Printing Office, 1968 , p. 15

19 Government of Republic of Mauritius, The History of Mauritius: The British Period 1810-1968, <http://www.govmu.org/English/ExploreMauritius/Page s/History.aspx\#dutch>

20 The UK's unilateral claim over the Chagos Archipelago as BIOT was due to an agreement between the United Kingdom and the United States on the leasing of the entire Diego Garcia Island, the largest island in the Chagos archipelago, as the American Navy Military Base in the Indian Ocean. Peter H. Sand, United States and Britain in Diego Garcia - The Future of a Controversial Base, New York: Palgrave MacMillon, 2009, p. 25.

21 "Unilateral acts have been defined in nearly all of the literature, without major differences between authors, as the expression of will formulated by a subject of the international legal order to produce legal effects at the international level", in Santiago Uris Molliner "Unilateral Acts and Public International Law: Delimitation of a Susceptible Figure to A Common Legal Regime", Thesis, Universitat Jaume I, Spain, 2001, p. 59; and "the Unilateral Legal Act (Declaration) means an unequivocal, autonomous expression of will, formulated publicly by one or more States in relation to one or more other States, the international community as a whole or an international organization, intending to acquire international legal obligations", International Law Commission, Second Report on Unilateral Act of States, 14 April and 10 May 1999, UN Doc. A / CN.4 / 500, Chapter II, p. 200 
Britain, but also Mauritius and the inhabitants of the Chagos Islands, Chagossians. In this case, British actions that were not based on an agreement between the two countries caused Mauritius as an integrated country to the Chagos Islands, having lost its territory. ${ }^{22}$ The Chagos Archipelago has been disputed between Mauritius and the UK since their establishment as BIOT in $1965 .{ }^{23}$ Until now, there has been no resolution of the seizure of the region because the negotiation efforts carried out between Mauritius and Britain to resolve this problem have often failed and have not resulted in a solution that is acceptable to both parties. ${ }^{24}$

In fact, the determination of the Chagos Archipelago as BIOT was accompanied by the British policy to vacate the Chagos Archipelago area based on national security reasons, even though this policy was based on the British agreement with the United States regarding the construction of a United States naval military base to be built on Diego Garcia Island. ${ }^{2526} \mathrm{At}$ that time, the British government relocated all Chagossians from the Chagos Archipelago and this policy was carried out without prior consultation and dialogue with Chagossians. ${ }^{27}$ Some of the methods in which the British Government applied to vacate the area at that time included orders for Chagossians to be obliged to move and leave the Chagos Archipelago;

Ibid.

23 Wenban-Smith, and M. Carter, Chagos: A History, Exploration, Exploitation, Expulsion, London: Chagos Conservation Trust, 2016

$24 \quad$ lbid.

25 Diego Garcia is the largest island in the Chagos archipelago.

26 The area sterilization and evacuation of the Chagos Archipelago were motivated by an agreement between Britain and America regarding the construction of an American Military Base on Diego Garcia Island, in which the construction process required an empty and secret territory. Peter H. Sand, United States and Britain in Diego Garcia..., Loc. Cit.

27 Christian Nauvel, "A Return from Exile in Sight? The Chagossians and Their Struggle", Journal of International Human Rights, Vol. 5, No. 1, 2007, p. 96. closure of copra plantations which are one of the Chagossians' main sources of income; as well as a prohibition on returning to the Chagos Archipelago for Chagossians who at the time were outside the Chagos Islands. ${ }^{28}$

Besides, the residences, facilities and private property belonged to Chagossians as well as burials of Chagossians ancestors who were left in the area were also destroyed to facilitate the sterilization process of the Chagos Archipelago. ${ }^{29}$ In the end, the Chagossians were stranded on the coast of Mauritius and the island of Seychelles without any shelter or compensation. ${ }^{30}$ Britain also issued several regulations that legitimize the removal of Chagossians and prohibit them from returning to the island they once occupied. ${ }^{3132}$ Several attempts have been made by the Chagossians to fight for the right to return to the Chagos Islands. ${ }^{33}$ However, the actions taken by Chagossians to obtain recognition, permission and access to return to the Chagos Islands, did not get a favorable response from the UK. ${ }^{34}$

Based on the explanation above, there are two problems, namely (1) the legality of the status of the Chagos Archipelago as BIOT and (2) the forced displacement of Chagossians and their prohibition from returning to the Chagos Archipelago by the UK. In this case, the determination of the status of the Chagos Archipelago as BIOT

28 Awaz Raoof, Briefing: Still Deposed-The Battle of Chagos Islanders to Return to Their Homeland, United Kingdom: Minority Rights Group International, 2014, p. 2

29 Ibid.

30 David Vine (et.al), The Expulsion and Impoverishment of the Chagossian People, Report, 11 April 2005, p. 152-155 Christian Nauvel, Loc. Cit.

32 BIOT Immigration Ordinance 1971 (No.1 / 1971), Art. 4, 9, 10, 11, 12 (1) (g), amended by BIOT Immigration Ordinance 2000 which was also amended by BIOT Constitution Order in Council 2004 and BIOT Immigration Order in Council 2004

33 Christian Nauvel, Loc. Cit

34 Ibid. 
becomes an important element which can later determine the legality of the policies that have been issued by the UK in the region, including the British action to displace all Chagossians from their place of origin unilaterally that is related to the concept and development of Human Rights and the role of the state in it.

\section{B. DECOLONIZATION: UTI POSSIDETIS JURIS AND SELF-DETERMINATION PRINCIPLE}

The Principle of Uti Possidetis Juris is one of the principles in international law which states that the boundaries of the territory of a new State will follow the territorial boundaries of the State when it was occupied previously. ${ }^{35}$ This principle stems from Roman private law which prohibits multiple ownership of a single property. ${ }^{36}$ At that time, this principle was aimed to maintain the status quo of ownership of a property. ${ }^{37}$ During the colonization period, especially in Latin America, the principle of Uti Possidetis Juris developed into a principle of ownership based on the fact of power in the field to prevent conflicts between fellow colonizing countries in expanding their respective powers. ${ }^{38}$ The colonial powers were free to expand their power in areas that still had the status of Terra Nuliius, but were not allowed to renew the limits of colonialism that were already owned by other countries. ${ }^{39}$

This principle began after the war between Spain and France against Portugal in $1801^{40}$ and began to develop since the $19^{\text {th }}$ century on the American continent when Latin American countries gained

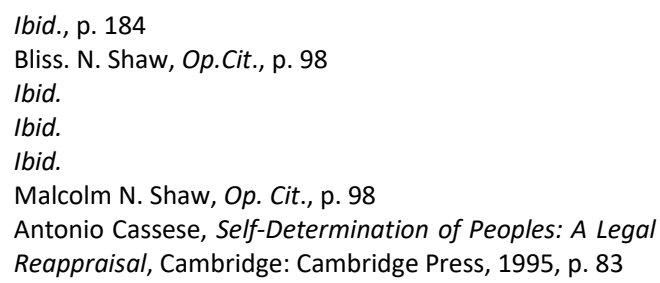

independence soon after the Spanish empire collapsed. ${ }^{41}$ During its development, the International Court of Justice adopted this principle in resolving border disputes between countries, for example when the International Court of Justice resolved the Frontier Dispute Case. ${ }^{42}$ This principle was also adopted by the Organization of African Unity in resolution 1964 which stipulates that all countries must respect borders in colonial times. ${ }^{43}$ Because there are quite a several disputes that have used the Uti Possidetis Juris principle, Martin Dixon stated that this principle has now become a principle of customary international law by its general application. ${ }^{44}$ The main purpose of this principle is to prevent the independence and stability of the nascent State from being compromised or threatened by challenges to its borders. ${ }^{45}$

Self-determination (self-determination) is a principle that has a major role in liberating the colonies in Asia and Africa, as this is supported by General Assembly Resolution 1514 (XV) dated December 14, 1960 which states that every colony has the right to determine fate itself and reinforced by General Assembly Resolution 1541 (XV) December 15, 1960. The provisions in article 1 of the International Covenant on Civil and Political Rights (ICCPR) also reaffirm the application of this principle.

In the discussion of international law, the principle of self-determination refers to the legal right for a group of "people" to obtain a degree of autonomy from the ruler in a

42 Summary of Judgment in the Case Concerning the Frontier Dispute (Burkina Faso v. the Republic of Mali), ICJ, Reports, 1986.

43 Alina Kaczorowsca, The $5^{\text {th }}$ edition of Public International Law, Ireland: Routledge, 2015, p. 111.

44 Martin Dixon, Textbook on International Law, $4^{\text {th }}$ Ed., London: Blackstone, 2000, p. 154.

45 Huala Adolf, Op.Cit., p. 115 
region. ${ }^{46}$ The people in question must be clearly seen as a group that has the same identity and is closely related to that area. Traditionally this has been proven in two ways. First, by determining the extent to which these groups have the same race, ethnicity, language, religion, culture, history and territorial unity. Second, by looking at the extent to which these groups see themselves as "people" who are different from other groups, and the extent to which they can form a separate political entity. ${ }^{47}$

During its development, this principle is divided into two types, namely Internal SelfDetermination and External SelfDetermination. Internal self-determination is divided into two, namely those relating to the whole people, such as the election of the form of government and those only related to certain groups such as granting special autonomy to minority groups. ${ }^{48}$ Meanwhile, external self-determination includes actions of self-determination related to demands to separate from the parent country to form their state or join with other countries. ${ }^{49}$

External self-determination is generally applied in the decolonization process by involving residents in the process of determining the status of an area at the time of decolonization. ${ }^{50} \mathrm{In}$ some cases, this principle is exercised by holding a Plebiscite as a referendum or opinion poll. As a

46 Stereo Milena, On the Right to External SelfDetermination: "Selfistan's", Secession, and the Great Power's Rule, p. 3. <http://ssrn.com/abstract=1337172>

$47 \quad$ Ibid., p. 20

48 Bruno Simma (ed.), The Charter of the United Nations: A Commentary, New York: Oxford University Press, 1995, p. 64-65

49 The implementation of the Right to Self-Determination as a Contribution to Conflict Prevention: Report of the International Conference of Experts Held in Barcelona from 21 to 27 November 1998 Organized by the UNESCO Division of Human Rights Democracy and Peace and the UNESCO Center of Catalonia, p. 12. <httpp: // www.unpo.irg / downloads / THE\% 2OIMPLEMENTATION\% 200F\% 20THE\% 20RIGHT\% 20TO\% 20SELF.pdf $>$ ]

50 Bruno Simma, Op.Cit., p. 66 comparison as in the case of Western Sahara, it was determined that the referendum was conducted under UN supervision. ${ }^{51}$ While in the case of the 1999 East Timor referendum, UNAMET not only supervised but also organized the implementation of the referendum and its results. Meanwhile, to determine the status of the West Papua region, the opinion poll conducted at that time was supervised by the United Nations and the results were accepted through a UN General Assembly Resolution.

\section{RIGHTS TO FREEDOM OF MOVEMENTS AND ENFORCED POPULATION TRANSFER}

Freedom of Movements is a part of basic human rights concerns and is also closely related to the idea of self-determination for an individual. ${ }^{52}$ Freedom of movements is generally formed from the idea of an individual's freedom to enter the territory of a country, and vice versa, which is also often associated with restrictions formed in the immigration sector. ${ }^{53}$ The Right to Freedom of Movements is a fundamental and important human right that has been listed and regulated in several human rights legal instruments and the law of armed conflict. ${ }^{54}$ The first legal instrument to contain and recognize this right is Magna Charta $1215 .^{55}$ The Right to Freedom of Movements also

51 Anna Theofilopoulou, The United Nations and Western Sahara: A Never-Ending Affair, p. 2.

<http://www.usip.org/pubs/specialreports/sr166pdf>

52 Colin Harvey and Robert P. Barnidge, "Human Rights, Free Movement and the Right to Leave in International Law", International Journal of Refugee Law, Vol. 19, No. 1, 2007, p. 2

53 Satvinder S Juss, "Free Movement and the World Order", International Journal of Refugee Law, Vol. 16, No.3, 2004, p. 289; James AR Nafziger, "The General Admission of Aliens under International Law", American Journal of International Law, Vol. 77, No.4, 1983, p. 804

54 Canadian Association for Refugee and Forced Migration Studies-Online Research and Teaching Tools (CARFMSORTT), Freedom of Movements.

<http://rfmsot.apps01.yorku.ca/glossary-ofterms/freedom-of-movement/>

55 Ibid. 
regulated and contained in several international legal instruments, as in Article 9 of the UDHR regulates that, ${ }^{56}$ "No one shall be subjected to arbitrary arrest, detention or exile".

Furthermore, the provisions in the Article 13 of the UDHR also stated that everyone has the right to freedom of movement, resides in a place within the borders of the country, also has the right to leave the country, and return to his home country if he wishes. ${ }^{57}$ Then, the provisions in articles 12 and 13 of the ICCPR also state that every person who is in the territory of a country legally based on law, has the right to freedom of movement within the territory of the country; leave the territory of the country; and these rights cannot be limited without the existence of regulations or laws in force and are based on the interests of national security, public order, public health, morals and other rights which are also regulated in this convention. ${ }^{58}$ In this regard, it is also stipulated that no one may and can be deprived of their right to enter and/or visit their own country. ${ }^{59}$

The right to freedom of movement is manifested in three forms in the UDHR and

56 Art. 9 Universal Declaration of Human Rights 1948

57"(1) Everyone has the right to freedom of movement and residence within the borders of each state; (2) Everyone has the right to leave any country, including his own, and to return to his country. "Art. 13 Universal Declaration of Human Rights 1948

58 "(1) Everyone lawfully within the territory of a State shall, within that territory, have the right to liberty of movement and freedom to choose his residence; (2) Everyone shall be free to leave any country, including his own; (3) The above-mentioned rights shall not be subject to any restrictions except those which are provided by law, are necessary to protect national security, public order (ordre public), public health or morals or the rights and freedoms of others, and are consistent with the other rights recognized in the present Covenant" Art. 12 Par. (1), (2), and (3) International Covenant on Civil and Political Rights, 1966

59 "No one shall be arbitrarily deprived of the right to enter his own country.", Art. 12 Par. (4) International Covenant on Civil and Political Rights, 1966

60 The terms used are 'right to free movement' and 'right to freedom of movement', as generic terms encompassing both internal and external movement. It has this broad sense in many of the writings under discussion. Jane the ICCPR. ${ }^{60}$ First, this right includes the freedom for an individual to move, choose a place to live and settle in a place within the borders of the country where the individual is located. ${ }^{61}$ Second, this right includes the right of individuals to cross the international borders of a country which shows the freedom to leave a country including the country of origin of the individual. ${ }^{62}$ Third, this right also includes the freedom for the individual to return to his place or country of origin. ${ }^{63}$ With this right, a person has the freedom to choose and move, come, stay, leave, or return to an area based on the provisions of the applicable law.

The Right to Freedom of Movements is closely related to the right to freedom and security contained in article 9 of the ICCPR; the right to participate in public activities contained in the provisions of article 25 of the ICCPR; the right to peaceful association contained in the provisions of article 21 of the ICCPR; the right to freedom of association or assembly contained in article 22 of the ICCPR; the right to privacy contained in the provisions of article 17 of the ICCPR; and conditions related to the expulsion of

McAdam, "An Intellectual History of Freedom of Movement in International Law: The Right to Leave as Personal Liberty", Melbourne Journal of International Law, Vol. 12, No.1, 2011, p. 4

61 Art. 13 (2) UDHR; Art. 12 (2) ICCPR. Also refer to, "who suggests that the right of internal movement played an important role justifying white settler colonies 'exclusionary migration policies in the 19th century, since' free mobility in the interior of nations and equal access to the law were [asserted as] features that distinguished the civilized states from barbaric and despotic ones'. Migrants who were 'ignorant of republican virtues' could be cast as a threat to the colonies"' liberal institutions of self-rule "'. McKeown, Melancholy Order: Asian Migration and the Globalization of Borders, Columbia University Press, 2008, p. 9

62 UDHR Art 13 (2); ICCPR art 12 (2). This right is also related to the right to seek and enjoy asylum from another country for the violence they experienced in their previous country of origin. UDHR Art 14 (1). Also, refer to the Convention Relating to the Status of Refugees 'Refugee Convention' art. 33; Convention against Torture and Other Cruel, Inhuman or Degrading Treatment or Punishment art. 3; ICCPR arts 6 and 7

63 UDHR art. 13 (2); ICCPR art. 12 (4) 
foreigners contained in the provisions of article 13 of the ICCPR. ${ }^{64}$ These rights are rights that can be enjoyed absolutely. However, it can also be limited and reduced in some conditions based on applicable law. Based on the provisions in article 4 of the ICCPR, countries can take measures to reduce The Right to Freedom of Movements in emergencies that threaten the safety and existence of the state. These actions can only be carried out with due regard to the urgency of the action, and the consistency of the action with the obligations of the country concerned based on international law and the principle of non-discrimination of race, color, sex, language, or religion. ${ }^{65}$ Furthermore, this right can also be limited based on national law under the provisions in article 12 paragraph (3) of the ICCPR based on national security, public order, public health, morals, and the rights of others. ${ }^{66}$ Then, HRC explicitly stated that the restrictions imposed must also include measurements needed to protect the parties whose rights are limited. Several conditions in which the limitation of this right can be justified include the limitation of rights for individuals who are suspected and/or convicted of a criminal act; access to certain environmental areas; prohibition of access to certain private areas; and other nonaccessible areas that are owned by certain individuals or persons based on the right to privacy. ${ }^{67}$

64 Australian Government-Attorney's General Department, Loc.Cit.

65 Ibid., Also refer to, "In a time of public emergency which threatens the life of the nation and the existence of which is officially proclaimed, the States Parties to the present Covenant may take measures derogating from their obligations under the present Covenant to the extent strictly required by the exigencies of the situation, provided that such measures are not inconsistent with their other obligations under international law and do not involve discrimination solely on the ground of race, color, sex, language, religion or social origin, "Art. 4 Par. (1) ICCPR

66 "The above-mentioned rights shall not be subject to any restrictions except those which are provided by law, are
In further discussion, ICCPR General Comment No. 27: Article 12 (Freedom of Movement), states that "the enforced population transfers or mass expulsion is prohibited". ${ }^{68}$ This provision is also in line with the provisions in the Rome Statute which explicitly states that enforced population transfer is an action that is classified as a crime against humanity and is against the provisions of international law,

"Deportation or forcible transfer of population' means forced displacement of the persons concerned by expulsion or other coercive acts from the area in which they are lawfully present, without grounds permitted under international law"69

Overall, enforced population transfer is an act of forcibly moving a group of people carried out without the voluntary will of these people. $^{70}$

\section{THE APPLICATION OF INTERNATIONAL LAW PRINCIPLES IN CONTROL AND TERRITORIAL OWNERSHIP IN DESIGNATING THE CHAGOS ARCHIPELAGO AS BIOT}

One of the principles of international law in the control and ownership of the territory that is contained in the dispute over the Chagos archipelago is Cessie or transfer of

necessary to protect national security, public order (ordre public), public health or morals or the rights and freedoms of others, and are consistent with the other rights recognized in the present Covenant.", Art. 12 Para. (3).

$67 \quad$ Ibid.

68 Office of the High Commissioner for Human Rights (OHCHR), CCPR General Comment No. 27: Article 12 (Freedom of Movement), 02 November 1999, p. 5

69 Art. 7 Par. 2 Rome Statute of the International Criminal Court 1988

70 International Network to Promote the Rule of Law (INPROL), Forced Displacement and Housing, Land, And Property Ownership Challenges in Post-Conflict And Reconstruction, 2009, p. 1 
territory. ${ }^{71}$ This principle can be seen clearly in the fact that the sovereignty gained by Britain over the Chagos Archipelago since 1814 came from the agreement between Britain and France, namely the Treaty of Paris 1814, which stated the transfer of territories (colonies) controlled by France in the Indian Ocean region (including Mauritius, the Chagos Islands, and Seychelles) to England. ${ }^{72}$ Based on that treaty, Britain then had sovereignty over these territories and thus could exercise jurisdiction over these territories. ${ }^{73}$ In other words, these territories were no longer under French colonies but had changed hands to the British.

In subsequent practice, the emergence of a UN General Assembly resolution condemning colonialism in the world and calling for the abolition of these actions shows the support and pressure from the international community for countries that have colonies or colonies to immediately carry out the decolonization process, including Britain. $^{74}$ The decolonization referred to in this resolution is the action of the countries that have colonized areas to help prepare and provide independence for the areas under their control. ${ }^{75}$ The context of decolonization in question also includes the granting of the rights to residents of these colony areas to be able to determine their destiny. ${ }^{76}$ In this case, self-determination in question can be in the form of a desire to remain part of the ruling state, a desire to establish a new state, or even a desire to

71 Cessie is the transfer of territory from one country to another and often takes place in the framework of an agreement, Peter Malanczukt, Op. Cit., P. 148

72 Treaty of Paris 1814

73 Geoffrey Robertson QC, Op. Cit., P. 3

74 UNGA Resolution No. 1514 (XV) of 14 December 1960 and UNGA Resolution No. 1654 (XVI) of 27 November 1961

75 "Immediate steps shall be taken, in Trust and Non-SelfGoverning Territories or all other territories which have not yet attained independence, to transfer all powers to the peoples of those territories, without any conditions or reservations, by their freely expressed will and desire ... to enable them to enjoy complete independence and become part of another country. ${ }^{77}$ In essence, the decolonization process which aims to eliminate all forms of colonialism in the world requires real efforts from countries that have colonies to immediately liberate the controlled areas into a sovereign independent state while still involving the opinions of residents from the region.

Based on this explanation, Britain as a colony, namely for the territory of the Indian Ocean which includes Mauritius, the Chagos Islands, and Seychelles, is also required to immediately decolonize these areas. In this regard, Britain should take measures that can help prepare and provide support for these areas to become independent. In the context of determining the territory for a new country that is experiencing a decolonization process, the principle of international law used is "Uti Possidetis Juris" 78 which generally explains that the territory of a new country that is undergoing a decolonization process is the same and intact as the administrative boundaries of the region when it was still part of its colony. ${ }^{79}$ Thus, under ideal conditions, Britain also had to carry out decolonization by its contribution to ensure that complete territory to its colony remained the same when they became independent.

In the dispute over the Chagos archipelago, Britain did not carry out the decolonization process as it should by not maintaining and giving the whole territory which included the Chagos Archipelago to Mauritius when the area became

freedom. Any attempt aimed at the partial or total disruption of the national unity and the territorial integrity of a country is incompatible with the purposes and principles of the Charter of the United Nations ", UNGA Resolution No. 1514 (XV) of 14 December 1960

76 Ibid.

77 Stephen Allen, "Looking beyond the Bancoult Cases: International Law and the Prospect of Resettling the Chagos Islands", Human Rights Law Review, Vol. 7, No.3, 2007, p. 441-482.

78 Peter Malanczuk, Op. Cit., p. 78

79 Ibid. 
independent as administrative boundaries of the Mauritius territory when under British control. ${ }^{80}$ In this case, Britain actually separated the Chagos archipelago and designated it as BIOT before Mauritius became independent. ${ }^{81}$ This contradicts the principle of Uti Possidetis Juris, in which Britain should carry out the decolonization process of Mauritius while maintaining the Chagos Archipelago as part of the territory of Mauritius because since the Chagos Archipelago was discovered by France until they were handed over to the British, this area was an integrated part of the Mauritius territory. ${ }^{82}$ The separation of the Chagos Archipelago from Mauritius before it became independent by the British was incompatible with the decolonization process that Britain should have carried out against Mauritius.

Although the British actions described earlier contradict the principles of Uti Possidetis Juris which regulate the determination of the boundaries of new countries through the decolonization process, basically the British actions in claiming the Chagos Archipelago as BIOT can be justified under international law. ${ }^{83}$ In other words, there are scenarios for the application of other international legal principles that can be used to justify Britain's action to separate the Chagos Archipelago from Mauritius, namely, (1) Cessie, there is the transfer of the Chagos Archipelago from Mauritius to Britain based on an agreement from the representatives of the countries concerned. ${ }^{84}$, or (2) the Exercise of Rights to Self-Determinations through opinion polls or referendums conducted on Chagossians who show support for the separation of their

\footnotetext{
80 Geoffrey Robertson QC, Loc. Cit.

81 British Indian Ocean Territory Order (1965); Statutory Instrument of 1965 No. 1920 which later was amended by Statutory Instrument of 1968 No. 111

82 Geoffrey Robertson QC, Loc. Cit.

83 Sandra JTM Evers, and Marry Kooy (ed.), Op. Cit., p. 164165

$84 \quad$ Peter Malanczukt, Op. Cit., p. 148
}

territory of residence from Mauritius. ${ }^{85}$

Under ideal conditions, the two principles above could have been used by Britain to justify its actions when separating the Chagos Archipelago from Mauritius, but in reality, the conditions and facts related to Britain's claim over the Chagos Archipelago do not indicate the possibility of (1) an agreement from Mauritius to surrender its territory to the UK; or (2) there is agreement and support from Chagossians to separate their territory from Mauritius.

The principle of international law in territorial control, namely Cessie, where there must be the transfer of the Chagos Archipelago from Mauritius to Britain based on an agreement from the representatives of the countries concerned cannot be used to justify Britain's claim to the Chagos Archipelago as BIOT since representatives of the Mauritian government were present at the time of the negotiations in 1965 regarding the separation of the territory of the Chagos Archipelago did not agree to the British proposal for the separation of the territory. ${ }^{86}$ Even if it was agreed by the representatives of the Mauritian government at the meeting, the agreement also could not be considered valid because the representatives presented at the negotiations were not yet official Mauritian government officials who could represent the interests and views of Mauritius. After all, the area was not yet independent and had an official government structure. $^{87}$

Furthermore, the application of the international rights to self-determinations legal principle through opinion polls or referendums that can be conducted by

\footnotetext{
85 "The most important requirement before sovereignty over territory could pass from one State to another is that the" free and genuine concern of the people concerned "must be ascertained", East Timor (Portugal v Australia), Judgment, ICJ Reports 1995, p . 90

86 Peter H. Sand, United States and Britain in Diego Garcia..., Op. Cit., p. 69-83

87 Art. 7 Vienna Convention on the Law of Treaties (VCLT)
} 
Chagossians who show support for the separation of their territory of residence from Mauritius, also cannot be used to support British actions to claim the Chagos Archipelago as BIOT and separating the region from Mauritius since the UK did not involve Chagossians in making these policies. ${ }^{88}$

Based on the explanation above, it can be seen that there is no single principle of international law regarding territorial control and ownership that can justify Britain to separate the Chagos Archipelago from Mauritius before Mauritius's independence and claim the area as BIOT.

\section{E. THE STATUS OF THE CHAGOS ARCHIPELAGO AS BIOT BASED ON INTERNATIONAL LAW}

Before 1975, the concept of terra nullius (land or territory that was not owned by anyone) was used to justify the acquisition of a country over an area that was not under state sovereignty or control of another colony. ${ }^{89}$ The assumption that residents who live in the terra nullius area are considered "uncivilized" and do not have control or power over the areas where they live because the political, legal, and social systems of these local people are not the same as the prevailing system in Europe.$^{90}$ In its development, this concept has drawn a lot of criticism and has been discredited as a "legal term of art" because its views seem to ignore and isolate the existence of residents who cannot be separated from the region. ${ }^{91}$ The national

88 "Neither Mauritius nor the UK secured the genuine consent of the people of the territory when excising Chagos from Mauritius.", Sandra JTM Evers, and Marry Kooy (ed.), Op. Cit., p. 165

$89 \quad$ Ibid., p. 162

$90 \quad$ Ibid.

91 Refer to Mabo v. Queensland (no 2) [1992] 175 CLR 1 [Australia]; Western Australia v Commonwealth [1995] 128 ALR 12 [Australia]; Calder v. The Queen [1973] 8 DLR [3rd] 59 [Canada]; R v Sparrow [1990] 1 SCR 1075 courts in Australia and Canada have also argued that this concept's view of the local population is racist because it undermines the traditional systems and patterns of local people in regulating social life systems simply because they are considered a different system from those used in Europe. ${ }^{92}$ In its development, the discussion regarding the scope of the concept of terra nullius then only covers the condition that the area is not under the duality of another colony and no longer talks about the insignificance of the existence of the local population of the area. In this regard, the local inhabitants of the colonized area are still respected as a significant entity with close ties to the area. ${ }^{93}$

Based on the provisions in customary international law, the "Occupation / Occupation" of a terra nullius area is a lawful method based on a law that can be used to acquire an area to become a colony. ${ }^{94}$ Two elements that must be fulfilled to prove that there is an "effective occupation" of an area are (1) the will to control the area; and (2) there are concrete actions that demonstrate the sovereignty of the country concerned over the territory. ${ }^{95}$ Concerning the status of the Chagos Archipelago as BIOT, the Chagos Archipelago was originally a terra nullius region. ${ }^{96}$ which was later discovered and occupied by France until $1814 .^{97}$ France obtained sovereignty over the Chagos Archipelago based on the effective occupation carried out in the region by carrying out government and economic activities as well as carrying out social arrangements in the region. ${ }^{98}$

[Canada]; and Delgamuukw v. British Columbia [1997] 3 SCR 1010 [Canada].

$92 \quad$ Ibid.

93 Sandra JTM Evers, and Marry Kooy (ed.), Loc. Cit.

94 Western Sahara Case, Op.Cit., p. 12, par. 79-80

95 lbid.

96 The Chagos Archipelago is classified to Terra Nullius since the area was initially not occupied by anyone before its discovery by France. Geoffrey Robertson QC, Op. Cit., p. 3

$97 \quad$ Ibid.

$98 \quad$ Ibid. 
The provisions of customary international law also show that sovereignty over a territory can also be transferred or given (cessie) from one colony to another based on the agreement of these countries in a territorial transfer agreement, provided that the country that gives up the territory has the right over the territory that he handed over. ${ }^{99}$ A practical example of this provision is the Treaty of Paris 1814 in which France gave up sovereignty over the territories it controlled in the Indian Ocean region, including the Chagos archipelago to the British. ${ }^{100}$ Concerning the status of the Chagos islands, after the agreement later the Chagos Archipelago came under British sovereignty and became a British colony.

There are three basic characteristics of a colony, namely (1) it is an overseas territory; (2) having different geographic and political entities (territorial scope and separate regional administration and administration; and (3) there is domination by other entities over residents of local origin. ${ }^{101}$ Based on the "Salt-Water Theory", an area that is still under the government of a foreign entity should include an area separated by sea waters from the state that administers the area,

"A territory which is still under foreign rule should be separated by seawater from the metropolitan state "102

Principle IV of UN General Assembly Resolution No, 1541 (XV) establishes "non-

\footnotetext{
$99 \quad$ Peter Malanczukt, Op. Cit., p. 148

100 Sandra JTM Evers, and Marry Kooy (ed.), Op. Cit., p. 162

101 G. Alfredsson, Loc. Cit

102 Theodore Christakis, "Self-Determination, Territory Integrity, and Fait Accompli in the Case of Crimea", Heidelberg Journal of International Law, Vol. 75, No.1, 2015, p. 83

103 UNGA Resolution No. 1541 (XV) of 15 December 1960: Principles Which Should Guide Members in Determining Whether or not an Obligation Exist to Transmit the Information Called for under Article 73e of the Charter

104
}

self-governing territory" as an area that is geographically separated from the territory of the country that administers administrative governance over it and has a population whom its ethnicity is different from the population of the country that governs it. ${ }^{103}$

"Non-self-governing territory as one that is geographically separate, with population ethnically and / or culturally distinct from that of the metropolitan state administering it"

The non-self-governing territory is generally located far away from the country that carries out administrative administration there. ${ }^{104}$

Since then, after the determination of the Chagos Archipelago as BIOT by the United Kingdom, the Chagos Archipelago can be categorized as a non-self-governing territory of the UK. ${ }^{105}$ However, BIOT (Chagos islands) was never registered on the UN List of nonself-governing territories. ${ }^{106}$ In this case, the UK stated that the Chagos Archipelago region cannot be categorized as a non-selfgoverning territory because there is no resident population in the area, the UK stated that the people active in the area are only temporary workers who only come to the islands to work on plantations there. ${ }^{107}$ Whereas it is clear that the inhabitants of the Chagos Archipelago (Chagossians) are permanent residents who live and even existed and resided long before the British gained sovereignty over the Chagos

105 The Chagos Archipelago can be classified as a non-selfgoverning territory of the United Kingdom since the territory is geographically separate, with population ethnically and/or culturally distinct from the United Kingdom as the metropolitan state administering it.

106 Refer to The UN List of Non-Self-Governing Territories, < http://www.un.org/en/decolonization/nonselfgovterrito ries .shtml>

107 Lord Justice Laws in The Queen (Ex Parte Bancoult) v. Foreign and Commonwealth Office, Law Reports: Queen's Bench Division, 2001, p. 1080; and GMF Drower, Britain's Dependent Territories: A Fistful of Islands, Aldershot: Dartmouth, 1992, p. 149 
Islands. ${ }^{108}$

The British position which ignores the existence of Chagossians and covers up the fact that residents are living in the area then becomes the main reason for the many violations and unpleasant situations against Chagossians because these actions make the protection of Chagossians impossible.

International Court of Justice (ICJ) in the dispute over the territory of East Timor (Portugal v. Australia), stated that the most important condition that must be fulfilled before sovereignty over a territory that is transferred from one country to another is to obtain a "free and genuine concern of the people concerned" ${ }^{109}$ Furthermore, ICJ in its Advisory Opinion in the matter of Legal Status of South West Africa also stated that only the UN General Assembly can change the legal status of certain areas, states cannot unilaterally do this without (1) the approval of the UN General Assembly and (2) the free and informed consent of the people of the territory. ${ }^{110}$ Thus, the opinion and agreement of the inhabitants of an area to be transferred become a very important element in the process of changing the status of the area.

Furthermore, based on the case regarding the dispute over the West Papua region between Indonesia and the Netherlands with issues that are more or less similar to the claim of the Chagos Archipelago as BIOT, the collection of local people's opinion is a very important factor in determining the prevailing sovereignty in the region. ${ }^{111}$ In this case, the determination of

108 Chagossians are a group of slaves and their descendants who were brought from the Caribbean by France and settled in the Chagos Islands. Long before the United Kingdom finally acquire the Chagos Archipelago territory from France. Bernardo Gomes de Brito, Loc. Cit.; Richard Gifford, Loc.Cit .; Sydney Selvon, Loc.Cit.

109 East Timor (Portugal v. Australia), Judgment, ICJ Reports 1995, p. 90

110 International Status of South West Africa, Advisory Opinion, ICJ, Reports, 1950, p. 141-145

111 The territorial dispute of West Papua was solved by the referendum of the people of West Papua. Official Report the status of the Chagos Archipelago based on British unilateral claims basically could be resolved by determining the opinion of the Chagossians as residents of the region.

The international community generally condemned the British act of separating the Chagos Archipelago from Mauritius and then unilaterally claimed the area as BIOT. The UN General Assembly has issued several resolutions such as UN General Assembly Resolution No. $1514(X V)^{112}$, Resolution No. $2066(X X)^{113}$ on December 16, 1965; and Resolution No. 2357 (XXII) on 19 December $1967^{114}$ which overall condemned the British action. The Non-Aligned Movement also issued a Political Declaration stating support for Mauritius sovereignty over the Chagos archipelago which had previously been unilaterally separated and taken from Mauritius by the United Kingdom, which was contrary to the provisions of UN General Assembly Resolutions. ${ }^{115}$ In addition, in 1980, the Organization of African Unity (OAU) also issued a resolution demanding that the island of Diego Garcia be returned to Mauritius immediately. ${ }^{116}$ The UN General Assembly has also issued UN General Assembly Resolution No. 71/292 dated 22 June 2017 to request an Advisory Opinion from the ICJ regarding the dispute over the Chagos Archipelago region. ${ }^{117}$ The ICJ then issued an Advisory Opinion on the Legal Consequences of the Separation of the Chagos Archipelago from Mauritius in 1965, which stated that the process of decolonization of Mauritius was not lawfully completed when that country

on the Implementation of the Act of Free Choice by Minister for Home Affairs of Indonesia at Djajapura..., Loc. Cit

112 UNGA Resolution No. 1514 (XV) of 14 December 1960

113 UNGA Resolution No. 2066 (XX) of 16 December 1965

114 UNGA Resolution No. 2357 (XXII) of 19 December 1967

115 Report of the Select Committee on the Excision of the Chagos Archipelago, Mauritius Legislative Assembly Port Louis, Mauritius June 1983, Appendix P. 63.

$116 \mathrm{AHg} / \mathrm{Res}$ No. 99 (XVII) of 04 July 1980: Resolution on the Diego Garcia

117 UNGA Resolution 71/292 of 22 June 2017, Loc. Cit. 
acceded to independence and that the UK is under an obligation to bring to an end its administration of the Chagos Archipelago as rapidly as possible. ${ }^{118}$ In this case, the ICJ concluded that the process of the Chagos Archipelago detachment from Mauritius detachment was not based on the free and genuine expression of the will of the people concerned and in the process of decolonization of Mauritius, the United Kingdom, as the administering Power, is required to respect the territorial integrity of that country, including the Chagos Archipelago. ${ }^{119}$

\section{F. THE RELOCATION OF CHAGOSSIANS FROM THE CHAGOS ARCHIPELAGO, THE PROHIBITION ON RETURNING AND RE- ESTABLISHING AS ENFORCED POPULATION TRANSFER}

The most important element of Enforced Population Transfer is the unwillingness of people to move and leave their place of residence or origin. ${ }^{120}$ This lack of a voluntary will can be caused by direct coercion such as terror, persecution, acts of violence, evictions carried out against them, or direct forced action such as an embargo or closure of access to certain needs in an area to make residents in the area leave the place. ${ }^{121}$ In general, there are many reasons ${ }^{122}$ and methods ${ }^{123}$ of the Enforced Population Transfer act. Reasons for an Enforced

118 Legal Consequences of the Separation of the Chagos Archipelago from Mauritius in 1965, Advisory Opinion, ICJ, Reports, 2019

119 Ibid.

< https://www.icj-cij.org/en/case/169>

120 International Network to Promote the Rule of Law (INPROL), Loc.Cit.

121 As a reference, Enforced Population Transfer in Yugoslavia and Palestine were carried out by force, persecution, and direct expulsion while in Thailand, it was executed by Instruction and resettlement policies of forced displacement made by the local government.

122 Handbook for the Protection of the Internally Displaced Person Release 2007, Loc.Cit.
Population Transfer can include reasons for security, conservation, health, public order, and even occupation of an area. The methods used in the Enforced Population Transfer could vary from violence to appeals and assistance with the implementations of particular policies. ${ }^{124}$ Based on the cases related to Enforced Population Transfer, actors that may take this action include the government of the country of origin of the displaced population; civil entity; or even a foreign entity who performs this action for some purpose. ${ }^{125}$

In the matter of relocating Chagossians from the Chagos Islands, it is known that the British did not carry out direct coercion to evict Chagossians from the Chagos archipelago, but the British told them that the oil palm and sugar cane plantations in the region as the main livelihood of the Chagossians would be completely closed and stopped. managed. ${ }^{126}$ Besides, Britain also stated that the Chagos Archipelago area must be vacated and ports and transportation facilities to the region will also be closed. ${ }^{127}$ The provision of this kind of information by the British was the main reason Chagossians were forced to leave the Chagos archipelago. Information on the closure of plantations and factories as their main source of livelihood and the closure of access to the Chagos Archipelago will make it difficult for

123 Some of the methods used in Forced Displacement are generally forced to leave their residence, expulsion, or relocation to other places that have been determined. Ibid

124 Handbook for the Protection of the Internally Displaced Person Release 2007, Loc. Cit

125 Forced Displacement in Palestine was done by the Israe Government; the Forced Displacement that occurred against Bosnian Non-Serbs was carried out by the Yugoslav Government and Ethnic Serbs, while the actions that occurred in Thailand were carried out by the local Government.

126 Peter H. Sand, United States and Britain in Diego Garcia..., Op. Cit., p. 15-33

127 Ibid. 
Chagossians to survive in the region. ${ }^{128}$ The British government did not enforce violence against Chagossians. ${ }^{129}$ However, the information and British statements were sufficient to compel the Chagossians to leave their homes. ${ }^{130}$ The fulfillment of this compulsion is sufficient to identify the relocation of Chagossians from the Chagos Archipelago as a form of Enforced Population Transfer.

In the case of the forced relocation that occurred to Chagossians, the party or actor who carried out the action was the British Government, which was the government of a colony that had sovereignty over the Chagos archipelago. Where the reason used by the UK in doing this is in the interests of national security stability. ${ }^{131}$ This action taken as a whole was carried out by establishing policies to sterilize the Chagos Islands, relocating Chagossians to the Mauritius and Seychelles areas, and establishing regulations that prohibit them from returning to Chagos Archipelago areas. ${ }^{132}$

In general, although the main and most important element of Enforced Population Transfer is compulsion (absence of a voluntary will) to leave one place and move to another place, in its development, there are also other elements of action that accompany the enforced population transfer itself. Based on the enforced population transfers that occurred to Chagossians, and

128 Ibid.

129 However, violence was also used against those who refused to leave, refer to David Vine, Island of Shame..., Loc. Cit., p. 112-114

130 Peter H. Sand, United States and Britain in Diego Garcia..., Loc. Cit.

131 Bancoult Case II, Op.Cit. p. 94

132 Peter H. Sand, United States and Britain in Diego Garcia..., Op. Cit., p. 43-50 and 69-112; also refer to BIOT Constitution Order in Council 2004 and BIOT Immigration Order in Council 2004

133 Chagossians were prevented from returning with the BIOT Constitution Order in Council 2004 and BIOT Immigration Order in Council 2004; residents who are relocated in Thailand are prohibited from returning due to the Thailand Forest Policy 1985, Palestinian residents similar cases that occurred to Palestinians, Bosnians ethnic non-Serbs, and residents of Thailand, the forced displacement that occurred to them as a whole was accompanied by efforts made to deter and it even closes the possibility for the displaced population to return to their place of origin. ${ }^{133}$ These efforts include the creation of regulations stipulating that their areas of origin are designated as prohibited areas and may not be entered by civilians without permission, such as in the Chagos Archipelago, Palestinian villages that have been occupied by Israel, and forests in Thailand; or the destruction of private property assets such as houses, public facilities, and places of worship in the area so that the area can no longer be used as a residential area.

One of the fundamental rights that are closely related to the problem of an enforced population transfer that occurs against Chagossians is the right to stay and return to their place of origin, which is a group of rights to freedom of movement. ${ }^{134}$ These rights are fundamental and important human rights that have been listed and regulated in several human rights legal instruments and the law of armed conflict. ${ }^{135}$

British actions against Chagossians in effect violated the right to freedom of movement which is protected by international law. The UK's Enforced

are prohibited from returning with the designation of their previous residence as Closed Military Areas, Caiman C., Loc. Cit.

134 This right includes (1) freedom for an individual to move, choose a place to live, and settle in a place within the borders of the country where the individual is located; (2) the right of individuals to cross the international borders of a country which indicates freedom to leave a country including the country of origin of the individual; and (3) freedom for the individual to return to the place or country. Art. 13 (2) UDHR; Art. 12 (2) ICCPR; UDHR art 13 (2); ICCPR art 12 (2); UDHR art. 13 (2); ICCPR art. 12 (4)

135 Canadian Association for Refugee and Forced Migration Studies-Online Research and Teaching Tools (CARFMSORTT), Loc. Cit. 
Population Transfer to Chagossians violates the provisions in articles 12 and 13 of the ICCPR which state that every person who is in the territory of a country legally based on law, has the right to freedom of movement within the territory of the country; leave the territory of the country; and these rights cannot be limited without the existence of regulations or laws in force and based on the interests of national security, public order, public health, morals and other rights which are also regulated in this convention. ${ }^{136}$ This British action in particular contradicts the provisions of article 12 paragraph (4) of the ICCPR which states that no one may and can be deprived of his right to enter and / or visit his own country. ${ }^{137}$

"No one shall be arbitrarily deprived of the right to enter his own country."138

This provision is also supported by the provisions in Article 9 of the UDHR which stipulates that, ${ }^{139}$

"No one shall be subjected to arbitrary arrest, detention or exile";

and the provisions in article 13 of the UDHR which also state that every person has the right to freedom of movement and movement (Right to Freedom of Movements), resides in a place within the borders of the country, also has the right to leave the country, and return to his country of origin if he so wishes. ${ }^{140}$

Apart from this right, as a party experiencing a Forced Displacement,

136 "(1) Everyone lawfully within the territory of a State shall, within that territory, have the right to liberty of movement and freedom to choose his residence; (2) Everyone shall be free to leave any country, including his own; (3) The above-mentioned rights shall not be subject to any restrictions except those which are provided by law, are necessary to protect national security, public order (ordre public), public health or morals or the rights and freedoms of others, and are consistent with the other rights recognized in the present Covenant. " Art. 12 Par. (1), (2), and (3) International Covenant on Civil and Political Rights, 1966

137 Art. 12 Par. (4) International Covenant on Civil and Political Rights, 1966

138 Ibid.
Chagossians are entitled to compensation and protection before, during, and after the forced displacement is carried out. ${ }^{141}$ As stipulated in article 49 of Geneva Convention IV 1949 which stipulates that in certain conditions where the transfer must be carried out, the government must ensure that there are adequate protection and accommodation for the population concerned,

"The Occupying Power undertaking such transfers or evacuations shall ensure, to the greatest practicable extent, that proper accommodation is provided to receive the protected persons, that the removals are impacted in satisfactory conditions of hygiene, health, safety and nutrition, and that members of the same family are not separated. ${ }^{1142}$.

In this case, prior to forced displacement, Chagossians had the right to know and get information about their transfer from the Chagos archipelago, but of course, this is inversely proportional to the existing facts because Chagossians were not given any explanations of the real reason they were moved. ${ }^{143}$ At the time of this transfer process, based on the provisions regarding Forced Displacement, Chagossians also have the right to compensation for the personal assets they have left behind, get replacement housing, and health and social protection. ${ }^{144}$ However, this right did not materialize as it

139 Art. 9 Universal Declaration of Human Rights 1948

140 “(1) Everyone has the right to freedom of movement and residence within the borders of each state; (2) Everyone has the right to leave any country, including his own, and to return to his country." Art. 13 Universal Declaration of Human Rights 1948

141 Susan Forbes Martin, Loc. Cit.

142 Art. 49 par.3 Geneva Convention IV 1949

143 When the transfer occurred, they were only informed that the plantations in the area would be closed, and they were not given any explanation that the area would be designated as BIOT and used as the United States Military Main Base.

144 Principle 7, 9, 18, 19, 20, 23, 25 Guiding Principles on Internal Displacement 
should. ${ }^{145}$

Even under ideal conditions, relocation of Chagossians should be temporary relocation where they can later return to their original places of residence and the government is responsible for ensuring that the process of returning home is carried out through the provision of facilities and infrastructure for their return, or other actions required. ${ }^{146}$ As the provisions in Article 49 of Geneva Convention IV 1949, which stipulates that,

"Nevertheless, the Occupying

Power may undertake the total or partial evacuation of a given area if the security of the population or imperative military reasons so demand. Such evacuations may not involve the displacement of protected persons outside the bounds of the occupied territory except when for material reasons it is impossible to avoid such displacement. Persons thus evacuated shall be transferred back to their homes as soon as hostilities in the area in question have ceased. ${ }^{147}$

However, based on the facts regarding the current condition of the Chagossians, there is very little chance for them to be able to return to their homes and hometowns, the Chagos Archipelago.

In general, during the relocation process, the basic rights of Chagossians as displaced people must also be protected by the government concerned, although again this can not be realized properly because at the time Chagossians were in residential areas in the Mauritius and Seychelles areas, the location of the Chagossians settlement after

145 Peter H. Sand, United States and Britain in Diego Garcia..., Op. Cit., P. 15-33

146 "Apart from the claim for sovereignty over Chagos, all the other points were agreeable to the British government including a proposition that, in the event of excision, the islands would be returned to Mauritius when not needed relocation, they are often discriminated against, humiliated, and even ostracized. ${ }^{148}$

\section{G. CONCLUSION}

Based on the Advisory Opinion issued by the ICJ regarding the Legal Consequences of the Separation of the Chagos Archipelago from Mauritius in 1965, the Chagos archipelago is recognized as an area that should remain integrated within the territory of Mauritius and its designation as BIOT is contrary to the principles and provisions of international law that are the principle of right to selfdetermination, uti posidetis juris and cessie. The UK therefore is obligated to hand back the territory to Mauritius. Furthermore, the UN Secretary-General can initiate (supervised by representatives of several neutral countries) other alternatives, such as the use of the mechanism for the implementation of the rights to self-determination through a referendum by the Chagossian, that may provide the final outcome of the status of Chagos Archipelago. This will reflect the free and genuine expression of the will of the Chagossians as the people of the region.

In regards to enforced population transfer carried out by the UK to Chagossians, the UK at least has two obligations as consequences of its violation. First, the UK returns Chagossians to their original place of residence, namely the Chagos Archipelago, accompanied by the provision of settlements and public facilities for Chagossians in the area and compensation. Second, the provision of compensation and provision of new and appropriate residential areas for all Chagossians in other areas outside the Chagos Archipelago region

by the UK government", see Evidence of the Select Committee chaired by Jean Claude de I'Estrac, 6 December 1982 and Principle 28-30 Guiding Principles on Internal Displacement

147 Art. 49 Par.2 Geneva Convention IV 1949

148 Sandra JTM Evers, and Marry Kooy (ed.), Op. Cit., p. 60 


\section{REFERENCES}

\section{Books}

A. Setiawan Abadi, Yayasan Obor Indonesia, Jakarta: 1993

Arkehurst, Michael, Modern Introduction to International Law, George Allenand Unwin, London, 1977

Bandjunis, V.B., Diego Garcia: Creation of the Indian Ocean Base, Writer's Showcase, San Jose, 2001

Bernhardt, Rudolf (ed.), Encyclopedia of Public International Law Volume II, Elsevier Science B.V., Amsterdam, 1995

Bhatt, the Strategic Role of the Indian Ocean in World Politics: The Case of Diego Garcia, Ajanta, New Delhi, 1992.

Bledsoe, Robert L., dan Boczek, Boleslaw A., The International Law Dictionary, Clio Press, Oxford, 1987

Boer Mauna, Hukum Internasional, PT. Alumni, Bandung, 2005

Boka'e, Niha, Palestinian Internally Displaced Person inside Israel: Challenging the Solid Structures, Badil Resource Centre for Palestinian Residency and Refugee Rights, 2003

Brito, Bernardo Gomes de, Tragic Maritime History, Cambridge, Hakluyt Society at the University Press, 1735

Brownlie, Ian, Principles of Public International Law, Oxford University Press, Oxford, 1979.

Cassese, Antonio, Self-Determiniation of Peoples: A Legal Reapparaisal, Cambrigde Press, Cambridge, 1995

De l'Estrac, J.C. (Chairman), Mauritius Legislative Committee Report of the Select Committee on the Excision of the Chagos Archipelago, Government Printer, Port Louis, 1983

Degan, Vladimir Developments in International Law: Sources of International Law, Martinus Nijhoff Publishers, The Netherlands, 1997.
Dixon, Martin, Textbook on International Law, 4th Ed., Blackstone, London, 2000.

Evers, Sandra J.T.M, and Marry Kooy (ed.), African History: Eviction from the Chagos Islands Displacement and Struggle for Identity Against Two World Powers, BRILL, Leiden, 1992.

Gibran, Daniel, The Falkland War: Britain Versus the Past in the South Atlantic, McFarland \& Company, Inc., Jefferson North Carolina, 1998.

Glahn, Gerhard von, Law Among Nations: An Introduction to Public Intemational Law, Fourth Edition, Macmillan Publishing Co. Inc., New York, 1981

Gneg, D.W., International Law, 2nd Edition, Butterworths, London, 1976

H., Cohen, The Present Absentees: The Palestinian Refugees in Istrael since 1948, The Institute for Israelin-Arab Studies, Jerussalem, 2001

Harris, D.J., Cases and Materials on International Law, Sweet and Maxwell, London, 1979.

Hillier, Tim, Sourcebook on Public of International Law, Cavendish Publishing Limited, Great Britain, 1998.

Hingorani, R.C., Modern International Law. Second Edition, Oxford \& IBH Publishing Co., New Delhi, 1982

Huala Adolf, Aspek-Aspek Negara dalam Hukum Internasional, Rajawali, Jakarta, 1995

I Wayan Parthiana, Pengantar Hukum Internasional, Penerbit Mandar Maju, Bandung, 2003

Jawahir Thantowi dan Pranoto Iskandar, Hukum Internasional Kontemporer, PT Refika Aditama, Bandung, 2006

Kaczorowsca, Alina, The 5th edition of Public International Law, Routledge, Ireland, 2015

Laremont, RR., Borders, Nationalism, and the African State, Lynne Reiner, London, 2005

Legrain,Phiillippe, Freedom of Movement, 
Minford-Shackleton.indd, 2016

Lipjhart, Arend, The Trauma of Decolonization: The Dutch and West New Guinea, Yale University Press, 1966

Madeley, J., Diego Garcia: A Contrast to the Falklands, Minority Rights Group, London, 1985

Malanczukt, Peter, Akehurst's Modern Introduction to International Law, 7th Ed., Routledge, New York, 1997

Mancham, J.R., War on America Seen from the Indian Ocean, Paragon, St. Paul, 2001

McKeown, Melancholy Order: Asian Migration and the Globalization of Borders, Columbia University Press, 2008

Mochtar Kusumaatmadja dan Etty R. Agoes, Pengantar Hukum Internasional, Alumni, Bandung, 2003

O'Brien, John, International Law, Cavendish Publishing Limited, London, 2001

Ott, David H., Public International Law in the Modern World, Pitman Publishing, London, 1987

Rabeea', Abu, Bedouins in the Negev: Displacement, Forced Resettlement, and Natural Zones, Oxford, 1999

Raoof, Awaz, Briefing: Still Deposed- The Battle of Chagos Islanders to Return to Their Homeland, Minority Rights Group International, United Kingdom 2014

Sand, Peter H., United States and Britain in Diego Garcia: The Future of Controversial Base, Palgrave Macmillan, United States of America, 2009

Selvon, Sydney, A new Comprehensive History of Mauritius: From the Beginning to This Day, Vol. 2, 2012.

Shaw, Malcolm N., International Law, 6th Ed., Cambridge University Press, Cambridge, 2008

Simons, A.S., Modern Mauritius: The Politics of Decolonization, University of Indiana Press, Bloomington, 1982

$\begin{array}{ccc}\text { Starke, J.G., } & \text { Pengantar Hukum } \\ \text { Internasional } & \text { Edisi Kesepuluh, } \\ \text { Terjemahan } & \text { Bambang Iriana }\end{array}$

Djajaatmadja, Sinar Grafika, Jakarta, 2006

Sugeng Istanto, Hukum Internasional, Universitas Atmajaya, Yogyakarta, 1988

T. Mulya Lubis, Ed., Hak Asasi Manusia dalam Masyarakat Dunia: Isu dan Tindakan, Terjemahan

Tanner, Marcus, The Conflict in the Former Yugoslavia, in Eastern Europe and the Commonwealth of Independent States, 7th Ed., Europa Publication Ltd., London, 1997.

Vine, David, Island of Shame. The Secret History of the U.S. Military Base on Diego Garcia, Princeton University Press, 2009

Wenban-Smith, dan M. Carter, Chagos: $A$ History, Exploration, Exploitation, Expulsion, Chagos Conservation Trust, London, 2016.

\section{Other Documents}

Allen, Stephen, "Looking beyond the Bancoult Cases: International Law and the Prospect of Resettling the Chagos Islands", Human Rights Law Review, Vol. 7, No.3, 2007

Baroness Chalker of Wallasey in Hansard House of Lords Debates on Mauritius Republic Bill, 19 May 1992

BIOT Constitution Order in Council 2004 BIOT Immigration Order in Council 2004

BIOT Immigration Ordinance 1971 (No. 1/1971) BIOT Immigration Ordinance 2000

BIOT Memorandum United Kingdom and United States of America 14 December 1966 BIOT Statutory Instrument of 1965 No. 1920

BIOT Statutory Instrument of 1968 No. 111 British Indian Ocean Territory Order of 1965

Canadian Association for Refugee and Forced Migration Studies-Online Research and Teaching Tools (CARFMS-ORTT), Freedom of
Movements. 
$<$ http://rfmsot.apps01.yorku.ca/glossaryof-terms/freedom-of-movement/>

Christakis, Theodore, "Self-Determination, Territory Integrity, and Fait Accompli in the Case of Crimea", Heidelberg Journal of International Law, Vol. 75, No.1, 2015

CRC, Sheppard (et.al.), "Reef and Islands of the Chagos Archipelago, Indian Ocean: Why it is the World's Largest No-Take Marine Protected Area", Aquatic Conservation: Marine and Freshwater Ecosystems Journal, Vol. 22, No. 2, 2012

Gifford, Richard, "The Chagos Island Islands: The Land Where Human Rights Hardly Ever Happened", Law Social Justice \& Global Development Journal, Vol. 1, No.1, 2004

Government of Republic of Mauritius, The History of Mauritius: The British Period 1810-1968, <http://www.govmu.org/English/Explor eMauritius/ Pages/History.aspx \#dutch>

Handbook for The Protection of the Internally Displaced Person Release 2007 Hansard House of Lords Debates, Mauritius RepublicBill: Baroness Chalker of Wallasey, 19 May 1992, Vol 537

Harvey, Colin and Robert P. Barnidge, "Human Rights, Free Movement and the Right to Leave in International Law", International Journal of Refugee Law, Vol. 19, No. 1, 2007

International Court of Justice, Advisory Opinion: Legal Consequences of the Separation of the Chagos Archipelago from Mauritius in 1965, 25 February 2019

International Law Commission Draft Declaration on Rights and Duties of States with Commentaries 1949

International Law Commission, "Second Report on Unilateral Act of States", 14 April and 10 May 1999, UN Doc. A/CN.4/500

International Law Commission, "Second Report on Unilateral Act of States", 14 April and 10 May 1999, UN Doc.
A/CN.4/500

International Law Commission, "Third report on Unilateral Acts of States by Mr. Victor Rodriguez Cedeno, Special Rapporteur", 17 Februari 2000, U.N. Doc A/CN.4/505

Juss, Satvinder S., "Free Movement and the World Order", International Journal of Refugee Law, Vol. 16, No.3, 2004

Legal Consequences of the Separation of the Chagos Archipelago from Mauritius in 1965, Advisory Opinion, ICJ, Reports, 2019 < https://www.icj-cij.org/en/case/169>

Ministry of Art and Culture of Mauritius, National Day Celebration: Enn Pei, Enn Nation, Enn Destin, Government of Republic Mauritius, 2013

Nafziger, James AR, "The General Admission of Aliens under International Law", American Journal of International Law, Vol. 77, No.4, 1983

NATO, The Kosovo Crisis in An International Law Perspective: Self-determination, Territorial Integrity and the NATO Intervention, Brussels: NATO Office of International and Press, 2001

Nauvel, Christian, "A Return from Exile in Sight? The Chagossians and Their Struggle", Journal of International Human Rights, Vol. 5, No. 1, 2007

Office of the High Commissioner for Human Rights (OHCHR), CCPR General Comment No.27: Article 12 (Freedom of Movement), 02 November 1999

Official Report on the Implementation of the Act of Free Choice by Minister for Home Affairs of Indonesia at Djajapura on August 5, 1969

Permanent Mission of Indonesia to the United Nations, Questioning the Unquestionable: An Overview of the Restoration of Papua into the Republic of Indonesia, New York, 2003

Press Release and Summary of Award of Permanent Court of Arbitration Chagos: Marine Protected Area Arbitration (Mauritius v. United Kingdom) 19 March 
2015

RIOM, Referendum Observer's Final Report, 23 March 2013

Selvon, Sydney, "A New Comprehensive History of Mauritius: From the Beginning to This Day", From British Mauritius to the 21st Century, Vol.2, 2012

The International Law Commission's Code of Crimes against Peace and Security of Mankind

Theofilopoulou, Anna, The United Nations and Western Sahara: A Never-Ending Affair, p. 2. $<$ http://www.usip.org/pubs/specialreport s/sr166pdf>

UNGA Resolution 71/292 of 22 June 2017: Request for Advisory Opinion of the International Court of Justice on the Legal Consequences of the Separation of the Chagos Archipelago from Mauritius in 1965

UNGA Resolution No. 1514 (XV) of 14 December 1960: Declaration on the Granting of Independence to Colonial Countries and People.

UNGA Resolution No. 1654 (XVI) of 27 November 1961: The Situation with Regard to the Implementation of Declaration on the Granting of Independence to Colonial Countries and People

UNGA Resolution No. 2066 (XX) of 16 December 1965: Question of Mauritius

UNGA Resolution No. 2232 (XXI) of 20 December 1966: Question of American Samoa, Antigua, Bahamas, Bermuda, British Virgin Islands, Cayman Islands, Cocos (Keeling) Islands, Dominica, Gilbert and Ellice Islands, Grenada, Guam, Mauritius, Montserrat, New Hebrides, Niue, Pitcairn, St. Helena, St. Kitts-Nevis-
Anguilla, St. Lucia St. Vincent, Seychelles, Solomon Islands, Tokelau Islands, Turks And Caicos Islands and the United States Virgin Islands

UNGA Resolution No. 2357 (XXII) of 19 December 1967: Question of American Samoa, Antigua, Bahamas, Bermuda, British Virgin Islands, Brunei, Cayman Islands, Cocos (Keeling) Islands, Dominica, Gilbert and Ellice Islands, Grenada, Guam, Mauritius, Montserrat, New Hebrides, Niue, Pitcairn, St. Helena, St. Kitts-Nevis-Anguilla, St. Lucia St. Vincent, Seychelles, Tokelau Islands, Solomon Islands, Turks and Caicos Islands and The United States Virgin Islands

UNGA Resolution No. 2625 (XXV) of 24 October 1970: Declaration on Principles of International Law concerning Friendly Relations and Co-operation among States in accordance with the Charter of the United Nation

United States Dept. of State Office of the Geographer, Commonwealth of Nations, U.S. Government Printing Office, 1968

\section{Legal Documents}

Geneva Convention IV 1949

International Covenant on Civil and Political Rights (ICCPR) 1966

International Covenant on Economic, Social and Cultural Rights (ICESCR) 1966

Protocol No. 4 to the Convention for the Protection of Human Rights and Fundamental Freedoms 1963

Rome Statute of the International Criminal Court 1988 United Nation Charter

Universal Declaration of Human Rights (UDHR) 1948 Vienna Convention on the Law of Treaties (VCLT) 1969 